\title{
How to Respond to Customer Complaints -from the Perspective of Argument Strength
}

\author{
Wen-Chin Tsao ${ }^{1}, \&$ Fang-Yu Su${ }^{2}$ \\ ${ }^{1}$ Professor, Department of Business Administration, National Chin-Yi University of Technology, Taichung, \\ Taiwan, Republic of China \\ ${ }^{2}$ Postgraduate of Department of Business Administration, National Chin-Yi University of Technology, Taichung, \\ Taiwan, Republic of China \\ Correspondence: Wen-Chin Tsao, Professor, Department of Business Administration, National Chin-Yi \\ University of Technology, Taichung, Taiwan, Republic of China.
}

Received: February 3, 2021

Accepted: March 15, 2021

Online Published: March 16, 2021

doi:10.5539/ibr.v14n4p24

URL: https://doi.org/10.5539/ibr.v14n4p24

\begin{abstract}
In this era of rapid network technology development, more and more people are sharing or receiving complaints about products or companies via online platforms. Related research finds that negative electronic word of mouth is perceived as credible and will have an adverse impact on companies. The purpose of this study is to explore how company response strategies to negative reviews affect corporate image and purchase intention. We aim to provide appropriate processing mechanisms to help companies reduce the damage of negative word-of-mouth. This study used an experimental design method, manipulating the experimental situation so that the subjects had a simulated personal experience with a company. A questionnaire was provided to collect subjects' opinions. There were 180 valid subjects. We utilized variance analysis to verify the hypotheses. This study had three primary findings: (1) Different response strategies to negative reviews will have different effects on corporate image and purchase intention. Among them, the accommodative strategy is significantly better than the other strategies - defensiveness and no action - for enhancing corporate image and purchase intention. (2) The impact of the response strategy on purchase intention will be moderated by the strength of the reviews' arguments, especially for accommodative strategies; however, this moderating effect does not occurred with respect to the impact of response strategies on corporate image. (3) Corporate image has a positive impact on purchase intention. Managerial implications for marketing managers are also discussed.
\end{abstract}

Keywords: response strategy, corporate image, negative eWOM, argument strength, accommodative strategy

\section{Introduction}

Previous research has observed that consumers believe that electronic word-of-mouth (eWOM) is more reliable than commercial information provided by companies, so they are more willing to actively search for and accept eWOM (Briggs \& Nigel, 1997; Tsao \& Hsieh, 2015). Due to the rapid development of network technology, consumers can more easily use various types of online media to share relevant information and their experiences with products or services (Hayes et al., 2018; Kim et al., 2018; Chu et al., 2019). Matute and Utrillas (2016) pointed out that $72 \%$ of consumers have great trust in online reviews. As a result, eWOM is important to online marketing management, and this topic has been deeply appreciated and explored by scholars for many years.

The banking and financial industry must rely on a large number of people to provide various services. Service failures are inevitable in such an industry, especially one with high personal contact (Tsao \& Jhang, 2019). If friction between service personnel and consumers results in negative word-of-mouth (WOM), it will inevitably cause consumers to have a negative perception of the company and affect their purchase decisions. This indicates how important eWOM is to the banking industry (Jan et al. 2018). In practice, the banking industry cannot completely avoid customer complaints caused by bad service; however, if the response to complaints is appropriate, it may be able to alleviate their impact on corporate image and consumer purchase intention.

In the past, research has focused on the consumer's personal point of view to explore how negative eWOM affects consumers' attitudes and behaviors, and few have discussed such issues from the perspective of corporate management (Zhang, 2016). Therefore, this study explored how companies respond to consumers' negative 
eWOM from a corporate perspective. It examined what corporations can do to reduce damage to their image and purchase intention. Cheung et al. (2012) found that the argument quality of information, the source credibility, the review consistency, and the review sidedness all have an impact on the review credibility, which in turn affects consumer evaluation of the company and purchase intention. The argument strength of the message released by consumers reflects the perceive extent of violation on their own rights. When the argument strength is stronger, the correlation between the company's response and consumer perception is bound to change. As such, this study used argument strength as a moderator in the research model. It explores the influence of company response strategies on corporate image and purchase intention, and it tries to determine the role argument strength plays.

Based on the following literature review and research questions, this study sets its independent variable as company response strategy, including accommodative strategy, defensive strategy and no action. We set argument strength as the moderator, with possible responses of strong or weak moderators. The interaction of response strategy and argument strength, and how they affect corporate image and purchase intention, was examined using six scenario designs. The findings of this study will provide future reference for banks, and firms in related industries, on how to deal with and respond to negative eWOM in order to reduce harm to the companies.

\section{Literature Review and Hypotheses}

\subsection{Company Response Strategy}

Company response strategy refers to a company's responses and actions after a consumer has complained of dissatisfaction with product or service (Chang et al., 2015). When companies face negative WOM, they can usually adopt one of the following eight ways of coping: outright denial, no comment, redirection of audience attention, voluntary admission of guilt, compliance with regulatory authority, implicit admission of guilt, admission of guilt, and voluntary proactive restitution action (Sherell \& Reidenbach, 1986). Lee and Song (2010) proposed three types of response methods for companies when facing negative WOM. They are the accommodative strategy, the defensive strategy, and the no action strategy. The so-called accommodative strategy is employed when a company explanations itself to the customer, apologizes, or makes a commitment to compensate the customer. The defensive strategy means that, when facing customer complaints, the company completely avoids its responsibility. The so-called no action strategy is when the company ignores customer complaints and does not respond at all (Zhang, 2013).

Past research has found that the impact of response strategy on the company is significant; that is, the correct response can reduce the negative impact of the crisis on the company (Miller \& Lessard, 2001). According to Coombs and Holladay (2008), apology is the best choice for a response strategy; when companies face negative situations, they argue it is unethical and unreasonable for companies to shirk their responsibilities. Therefore, the apology strategy has the most significant positive influence on corporate image (Bradford \& Garrett, 1995). Lyu (2012) found that whether the impact of the crisis is large or small, the use of rationalization strategies, such as adopting accommodative strategies, is more helpful to companies and favored by more companies.

Based on the above literature, this study argued that the different response strategies adopted by a company regarding customer complaints will affect its corporate image to varying degrees, and they will also affect consumers' subsequent behavioral intentions. Therefore, following Lee and Song (2010), this study divided companies' responses to customer complaints into three types - accommodative strategy, defensive strategy and no action - to carry out the subsequent experimental design scenarios.

\subsection{Corporate Image}

Nguyen and Leblan (2001) defined corporate image as the subjective attitudes and impressions formed by customers toward the products, services, or social activities provided by the company. Barnett et al. (2006) maintained that corporate image is the overall evaluation and judgment of consumers on the financial performance of the company and the influence of the company on society and the environment. Herbig and Milewicz (1995) suggested that corporate image includes corporate reputation. Corporate reputation is formed by perceptions and judgments acquired through long-term interaction between various groups and companies; consumers' perception of corporate reputation is related to corporate creditability.

Hawkins and Coney (2001) posited that corporate image has a significant impact on consumers' purchasing decisions. The study also confirmed that there is a positive correlation between corporate image and consumer purchase intention. Research by Graham and Bansal (2007) on the airline image and consumers' 
intention to pay found that for each one-point increase in airline reputation, consumers were willing to pay US $\$ 18$ more for a plane ticket, which shows the positive relationship between corporate image and purchase intention. Tucker and Melewar (2005) found in their research that negative WOM will not only damage corporate image, it will also affect consumers' subsequent behavioral intentions. This holds true even after the dissatisfaction of stakeholders dissipates based on repurchase willingness and WOM transmission.

According to Tkalac et al. (2019), compared to a strategy of no action, an accommodative strategy implemented by companies in the face of a crisis will have more of a positive impact on corporate image and consumer perception. Dean (2004) pointed out that in the response strategies adopted by a company facing a crisis, defensive strategies will have a greater negative impact on corporate image than accommodative strategies. Lee and Song (2010) indicated that the strategy of no action has a more significant positive impact on consumer perception than the defensive strategy. Based on the above, this study argues that when companies face negative eWOM, different response strategies will have different degrees of impact on their corporate image. Therefore, the following hypothesis is proposed:

H1: Different response strategies have different impacts on corporate image.

\subsection{Purchase Intention}

Spears and Singh (2004) stated that purchase intention refers to the responsive behavior of consumers after they evaluate a product overall. Khan and Azam (2016) also defined purchase intention as an individual's willingness to purchase a specific product or service. Related research shows that eWOM has become one of the important forces that influences consumer purchase intention (Bataineh, 2015; Thomas et al., 2006). Both positive and negative eWOM have an influence on consumers' purchase intention (East et al., 2008). In particular, negative word of mouth will have a significant adverse effect on purchase intention (Beneke et al., 2015).

McCollough (2000) held that consumers evaluate the company's response strategy, and the evaluation results affect the purchase intention. If consumers think that a company's response is acceptable, it helps to increase their purchase intention; on the contrary, if consumers think that a company's response method is less than acceptable, it will make consumers' purchase intentions decline. The apology strategy has a more favorable impact on consumer purchase intention than the defensive strategy (Turk et al., 2012). Lee and Cranage (2014) found that of the response strategies made by companies when they face negative WOM, the strategy of no action will have a more positive impact on consumer purchase intention than defensive strategies. Therefore, this study anticipates that the different ways companies respond to complaints will have varying degrees of influence on purchase intention. We propose the following hypothesis:

H2: Different response strategies will have a different impact on purchase intention.

\subsection{Argument Strength}

Argument strength refers to the degree to which the content of a message makes its receiver feel that the claim made by the message is strong. When the quality of the message is stronger, the influence on the attitude of the message recipient will be more significant (Schreiner et al., 2018). In a study of argument quality by Petty and Cacioppo (1986), messages are divided into categories of strong-argument messages and weak-argument messages. Among them, the message receiver perceives strong-argument messages to be more reliable, or of high quality; conversely, the message receiver perceives weak-argument messages to be relatively less reliable, or of lower quality. Dimmock et al. (2013) argued that the clearer the argument of the message source description, the higher the content quality; the higher the quality of the message, the more significant its impact on the receiver's attitude. Furthermore, the more realistic a message's description, the greater its impact on the attitude of the message recipient (Schreine et al., 2018).

Petty and Cacioppo (1986) indicated that high quality WOM makes consumers more persuaded and positive about products or services than low quality WOM. Lee (2012) suggested that high-quality reviews have more influence on consumers' purchasing intentions than reviews with low quality. Schreiner et al. (2018) stated that the stronger the tone of a message, the more significant the impact on consumers. In addition, Cheung et al. (2012) pointed out that argument strength has become an important factor in the degree of consumer response to information. When the argument strength is stronger, its influence on consumer decision-making variables such as the attitude towards the company and purchase intention is greater. Therefore, this study expects to find that the impact of corporate response to negative WOM on corporate image and purchase intention will be different depending on the argument strength of the 
negative WOM. The stronger the message's argument, the more disadvantageous it will be to the rescue of corporate image and purchase intention. On the basis of this literature review, the following hypotheses are proposed:

H3a: The correlation between company response strategies and corporate image will vary depending on argument strength.

H3b: The correlation between company response strategies and purchase intention will vary depending on argument strength.

\subsection{The Relationship between Corporate Image and Purchase Intention}

Robertson and Gatignon (1986) suggested that consumers will consider the quality of a company's products or services through the lens of its corporate image, which is also in line with the peripheral route of the elaboration likelihood model (ELM) mentioned by scholars (Petty \& Cacioppo, 1986). Corporate image provides consumers with a prior understanding of the products or services of a particular company, which can effectively reduce their uncertainty when making purchasing decisions. When consumers are unfamiliar with the products or services of a particular company, corporate image will become an important reference indicator. Companies with a good image are more easily accepted by consumers (Alpert \& Kamins, 1995), because a good corporate image has a positive incentive effect on consumers and can effectively enhance consumers' trust in the company (Casalo et al., 2007).

Bataineh (2015) found that corporate image has a direct impact on consumer purchase intention. When a company has a good corporate image, it will help to increase consumers' trust in the company, thereby increasing consumer purchase intention. Herbig and Milewicz (1995) held that when a company has better corporate image, consumers' purchase intentions for the products or services sold by the company are higher. Based on the above information, corporate image has a positive effect on promoting consumers' purchasing intention. Accordingly, the following hypothesis is proposed:

H4: Corporate image has a significant positive impact on purchase intention.

\section{Method}

\subsection{Design}

In the past, research on topics related to negative eWOM was mostly in the tourism industry, film and television entertainment industry, and telecommunications industry, and less in the financial industry (Tsao et al., 2015; Tsao \& Hsieh, 2015). In the financial industry, banking is among the more complicated sectors and has more employees (Lin, 2017). In organizations with more service personnel, the frequency of friction between service personnel and consumers is higher. Therefore, this study used the banking industry as the industry category for research.

This study assumes that if not manipulated by external forces, it is difficult to use the recall method to measure the perceived service errors of the customers and their interactions with service personnel. In order to improve the internal validity of the research, this study referred to Tsao (2018) and adopted an experimental design method. When introduced to virtual situations, the subjects were meant to act as they would in a real environment so as to measure their intuitive responses to the ways banks deal with complaints. This study divided company response strategies into categories of accommodative strategies, defensive strategies and no action strategies and divided argument strength into categories of strong and weak. This study used a 3 (response strategy: accommodative/defensive/no action) $\times 2$ (argument strength: strong/weak) between-subject factorial design. The participants for this study were publicly recruited from a community website, and non-random assignments of 6 experimental scenarios were made online.

\subsection{Development of Stimuli, Experimental Manipulation, and Measure Development}

Statistics on public complaints received by the Banking Bureau of the Financial Supervisory Commission (2019) show that the number of consumer complaints about poor attitudes of bank personnel ranks fifth among all complaint cases. This shows that consumers pay significant attention to bank service employee attitudes. Therefore, this study used the attitudes of bank counter staff as the main content of customer complaints in the virtual situations.

According to Lee and Song (2010), company response strategies are composed of accommodative strategies, defensive strategies and strategies of no action. Hence, this study used "apology" as a contextual manipulation for accommodative strategy, "avoiding responsibility" as a contextual manipulation for defensive strategy, and "not responding" as a contextual manipulation for no action (Zhang, 2013). 
Based on the relevant literature, argument strength is defined as the intensity of tone and content quality (including authenticity and clarity) of the substance of the message (Dimmock et al., 2013; Schreiner et al., 2018). Therefore, the intensity of the statement and the quality of the content were used to design and manipulate the situation. If, in the message left by the consumer, the tone of the complainant's statement is stronger and the content more realistic and clearer, the argument strength is considered stronger; otherwise, the argument strength is weaker. In order test argument strength, this study proposed three items in the questionnaire as follows: 1 . I think that the consumer's message is strong in words; 2 . I think the description in the consumer's message is realistic; 3. I think the description of the consumer's message is clear. These items were measured using a seven-point Likert-type scale, ranging from 1 (strongly disagree) to 7 (strongly agree).

For the manipulation criteria of the above two variables, this study proposed one of six virtual situations. An example would be argument strength: strong / response strategy: accommodative.

Online customer complaint (strong argument strength):

When I went to this bank for business on June 1, the attitude of the staff in the process was really bad. When I asked him questions, the teller answered me with a perfunctory attitude. For example, I asked how to fill in information on a form, and he replied to me: "Fill it as written above! Can't you read it yourself!" Yes, I'm really so free that I don't have anything else to do! I only came here to get your bad service. I will never come to this bank to do anything again!

Bank response strategy (accommodative strategy):

Dear customer: We are very sorry for your unpleasant experience in the bank. Please send your personal contact information to aaa@XXX.com, and we will send a specialist to contact you to understand the details of what happen that day, so that the bank can make further improvements and enhancements. Thanks for your cooperation.

The definitions and measurement of the dependent variables in this study are explained, as follows. Corporate image refers to the subjective attitude and impression of customers after evaluating the company as a whole (Nguyen \& Leblan, 2001; Barnett et al., 2006) based on the literature review, this study proposed seven measurement items to measure corporate image. Purchase intention refers to consumers' tendency to purchase a specific product or service (Khan \& Azam, 2016); based on the literature review, this study proposed 7 measurement items to measure purchase intention. All 14 items were measured using a seven-point Likert-type scale ranging from 1 (strongly disagree) to 7 (strongly agree). Appendix A shows the questionnaire items and reference literature sources.

\subsection{Participants and Experimental Procedure}

This study used convenience sampling to conduct the survey. Respondents were consumers who had done business with banks in the past year, and online platforms were used for the sample data collection. Google Forms was employed to create an online questionnaire, which was supplemented using the Wix.com web editor to edit the questionnaire and smooth out the test process. The questionnaires based on the six different situations were distributed on social media platforms. To avoid the bias of non-random assignments as much as possible, this study randomly changed the layout of the six hyperlinked URLs week by week.

The online platforms used for questionnaire distribution included a personal page on Facebook, a Facebook questionnaire exchange community, a Line community, and a personal Instagram page. Before completing the questionnaire, the subjects were asked to read an article about a scenario, so that the subjects could be familiar with the scenario before the pre-test. They then filled out the questionnaire after reading about how the bank handled the consumer's complaint. A total of 212 subjects were contacted in this study. After the questionnaires with incomplete and invalid answers or from non-target subjects were eliminated, the number of valid samples was 180 . The effective recovery rate was $85 \%$.

Among the subjects, 52 were male (28.9\%) and 128 were female (71.1\%). The majority were $21-30$ years old, with 122 subjects in that range (67.8\%), followed by 23 people $31-40$ years old (12.8\%). In terms of occupation, students accounted for the highest proportion, with 101 subjects $(56.1 \%)$, followed by those employed in the 
service industry, with 44 people (24.4\%). The number of business transactions with banks in the past year was mostly 1 to 5 times, applying to 141 people (78.3\%), followed by 6 to 10 times, with 25 people (13.9\%).

\section{Analysis and Results}

\subsection{Reliability and Validity Analysis, and Manipulation Check}

First, the reliability and validity of the constructs were tested. As shown in Table 1, the Cronbach's alpha of the three constructs were between 0.793 and 0.966 , all exceeding 0.7 , and at the same time, the composite reliability was greater than 0.6 . This shows that the three constructs all meet the standards for high internal consistency (Fornell, 1992). From Table 1 we can see that the factor loading of the 17 measurement items was between 0.715 and 0.933. Considering a judgment threshold greater than 0.7, this indicates that the three constructs are consistent with convergent validity (Hair et al., 2009).

Second, a manipulation check was conducted on the argument strength variation in the virtual experimental situation. In this study, 90 of the 180 valid questionnaires responded to the strong argument situation, and 90 responded to the weak argument situation. The mean of the argument strength reported when the subject was associated with the high argument strength situation was significantly greater than the mean of the low argument strength situation $\left(\mathrm{Mean}_{\text {strong }}=5.030\right.$, Mean $\left._{\text {weak }}=3.393 ; \mathrm{t}=9.109^{* * * *}, \mathrm{p}<0.001\right)$. Based on this, the manipulation of argument strength is shown to be appropriate and subsequent analysis can continue.

Table 1. Scale items and measured properties

\begin{tabular}{|c|c|c|c|c|c|c|c|}
\hline Construct & Items & Mean & S. D. & $\begin{array}{c}\text { Factor } \\
\text { loading }\end{array}$ & $\begin{array}{c}\text { Cronbach's } \\
\text { alpha }\end{array}$ & $\begin{array}{l}\text { Composite } \\
\text { reliability }\end{array}$ & AVE \\
\hline \multirow{3}{*}{$\begin{array}{l}\text { Argument } \\
\text { strength }\end{array}$} & A1 & 4.728 & 1.759 & 0.902 & \multirow{3}{*}{0.793} & \multirow{3}{*}{0.881} & \multirow{3}{*}{0.714} \\
\hline & $\mathrm{A} 2$ & 4.200 & 1.576 & 0.883 & & & \\
\hline & A3 & 3.706 & 1.848 & 0.740 & & & \\
\hline \multirow{7}{*}{ Corporate image } & $\mathrm{C} 1$ & 3.194 & 1.658 & 0.933 & \multirow{7}{*}{0.960} & \multirow{7}{*}{0.975} & \multirow{7}{*}{0.847} \\
\hline & $\mathrm{C} 2$ & 3.417 & 1.613 & 0.928 & & & \\
\hline & $\mathrm{C} 3$ & 3.033 & 1.542 & 0.924 & & & \\
\hline & $\mathrm{C} 4$ & 3.217 & 1.835 & 0.922 & & & \\
\hline & $\mathrm{C} 5$ & 3.267 & 1.851 & 0.920 & & & \\
\hline & C6 & 3.139 & 1.694 & 0.915 & & & \\
\hline & $\mathrm{C} 7$ & 3.161 & 1.708 & 0.899 & & & \\
\hline \multirow{7}{*}{$\begin{array}{l}\text { Purchase } \\
\text { intention }\end{array}$} & $\mathrm{P} 1$ & 3.372 & 1.568 & 0.888 & \multirow{7}{*}{0.966} & \multirow{7}{*}{0.942} & \multirow{7}{*}{0.699} \\
\hline & $\mathrm{P} 2$ & 3.289 & 1.504 & 0.863 & & & \\
\hline & P3 & 3.172 & 1.574 & 0.863 & & & \\
\hline & $\mathrm{P} 4$ & 2.967 & 1.596 & 0.862 & & & \\
\hline & P5 & 2.972 & 1.544 & 0.826 & & & \\
\hline & P6 & 3.000 & 1.737 & 0.825 & & & \\
\hline & P7 & 3.183 & 1.619 & 0.715 & & & \\
\hline
\end{tabular}

\subsection{Hypothesis Testing}

The hypotheses were tested using a $2 \times 2$ analysis of variance. As shown in Table 2, company response strategy revealed a significant effect on corporate image $\left(\mathrm{F}_{(2,174)}=91.451^{* * *} ; \mathrm{p}<0.001\right)$. Using a mean test, we found that the accommodative strategy was more effective than the defensive strategy in recovering corporate image $\left(\mathrm{Mean}_{\text {accommodative }}=4.738>\operatorname{Mean}_{\text {defensive }}=2.400 ; \mathrm{t}=12.090^{* * * *} ; \mathrm{p}<0.001\right)$ (see Table 3). At the same time, the accommodative strategy was more effective than no action in restoring corporate image $\left(\mathrm{Mean}_{\text {accommodative }}=4.738\right.$ $>$ Mean $_{\text {no action }}=2.474 ; \mathrm{t}=11.122^{* * *} ; \mathrm{p}<0.001$ ) (see Table 3). This demonstrates that the different response strategies will have different effects on corporate image. Among them, the accommodative strategy is significantly better than the other two strategies; however, there is no significant difference between defensiveness and no action $\left(\mathrm{Mean}_{\text {defensive }}=2.400<\mathrm{Mean}_{\text {no action }}=2.474 ; \mathrm{t}=-0.380 ; \mathrm{p}>0.05\right)$. As a result, $\mathrm{H} 1$ is supported.

Table 2. Two-way ANOVA test results (Dependent variable: Corporate image)

\begin{tabular}{lcc}
\hline & F & P \\
\hline Response strategies (A) & 91.451 & $0.000^{* * * *}$ \\
Argument strength (B) & 1.339 & 0.249 \\
$\mathrm{~A} \times \mathrm{B}$ & 1.279 & 0.281 \\
\hline
\end{tabular}

Note: ${ }^{*} \mathrm{p}<0.05,{ }^{* *} \mathrm{p}<0.01,{ }^{* * *} \mathrm{p}<0.001$ 
Table 3. Multiple comparisons and mean test

\begin{tabular}{|c|c|c|c|c|c|}
\hline $\begin{array}{l}\text { Dependent } \\
\text { variable }\end{array}$ & $\begin{array}{l}\text { Response strategy } \\
\text { (I) }\end{array}$ & Response strategy $(\mathrm{J})$ & $\begin{array}{l}\text { Mean difference } \\
(\mathrm{I}-\mathrm{J})\end{array}$ & $t$-value & $p$-value \\
\hline \multirow{6}{*}{$\begin{array}{l}\text { Corporate } \\
\text { image }\end{array}$} & \multirow{2}{*}{ Accommodative $(4.738)^{\mathrm{a}}$} & $\begin{array}{c}\text { Defensive } \\
(2.400)\end{array}$ & 2.338 & 12.090 & $0.000^{* * * *}$ \\
\hline & & $\begin{array}{c}\text { No action } \\
(2.474)\end{array}$ & 2.264 & 11.122 & $0.000^{* * *}$ \\
\hline & \multirow{2}{*}{$\begin{array}{l}\text { Defensive } \\
(2.400)\end{array}$} & $\begin{array}{c}\text { Accommodative } \\
(4.738)\end{array}$ & -2.338 & -12.090 & $0.000^{* * * *}$ \\
\hline & & $\begin{array}{c}\text { No action } \\
(2.474)\end{array}$ & -0.074 & -0.380 & 0.932 \\
\hline & \multirow{2}{*}{$\begin{array}{l}\text { No action } \\
(2.474)\end{array}$} & $\begin{array}{c}\text { Accommodative } \\
(4.738)\end{array}$ & -2.264 & -11.122 & $0.000^{* * * *}$ \\
\hline & & $\begin{array}{c}\text { Defensive } \\
(2.400)\end{array}$ & 0.074 & 0.380 & 0.932 \\
\hline
\end{tabular}

Note: ${ }^{*} \mathrm{p}<0.05,{ }^{* *} \mathrm{p}<0.01,{ }^{* * *} \mathrm{p}<0.001$

${ }^{\mathrm{a}}$ The figures in the brackets are the mean values.

As shown in Table 4, company response strategy revealed a significant effect on purchase intention $\left(\mathrm{F}_{(2,174)}=\right.$ $\left.47.590^{* * *} ; \mathrm{p}<0.001\right)$. After multiple comparisons, we found that the accommodative strategy was significantly more effective than the defensive strategy in improving purchase intention $\left(\mathrm{Mean}_{\text {accommodative }}=4.329>\right.$ Mean $_{\text {defensive }}=2.429 ; \mathrm{t}=8.902^{* * *} ; \mathrm{p}<0.001$ ) (see Table 5). In addition, the accommodative strategy increased purchase intention significantly more than no action $\left(\mathrm{Mean}_{\text {accommodative }}=4.4 .329>\mathrm{Mean}_{\text {no action }}=2.652 ; \mathrm{t}=\right.$ $7.641^{* * *} ; \mathrm{p}<0.001$ ) (see Table 5). This demonstrates that the different response strategies will have different effects on purchase intention. Accommodative strategies are significantly better than the other two strategies; however, there is no significant difference between defensive and no action strategies $\left(\mathrm{Mean}_{\text {defensive }}=2.429<\right.$ $\left.\mathrm{Mean}_{\text {no action }}=2.652 ; \mathrm{t}=-1.041 ; \mathrm{p}>0.05\right)$. As a result, $\mathrm{H} 2$ is supported.

Table 4. Two-way ANOVA test results (Dependent variable: Purchase intention)

\begin{tabular}{lcc}
\hline & F & P \\
\hline Response strategy (A) & 47.590 & $0.000^{* * * *}$ \\
Argument strength (B) & 1.876 & 0.172 \\
A $\times$ B & 3.119 & $0.047^{*}$ \\
\hline
\end{tabular}

Note: ${ }^{*} \mathrm{p}<0.05,{ }^{* *} \mathrm{p}<0.01,{ }^{* * *} \mathrm{p}<0.001$

Table 5. Multiple comparisons and mean test

\begin{tabular}{|c|c|c|c|c|c|}
\hline Dependent variable & Response strategy (I) & Response strategy $(\mathrm{J})$ & Mean difference (I-J) & t-value & p-value \\
\hline \multirow{6}{*}{ Purchase intention } & \multirow{2}{*}{ Accommodative (4.329) } & $\begin{array}{c}\text { Defensive } \\
(2.429)\end{array}$ & 1.900 & 8.902 & $0.000^{* * * * \times 1}$ \\
\hline & & $\begin{array}{l}\text { No action } \\
(2.652)\end{array}$ & 1.676 & 7.641 & $0.000^{* * * *}$ \\
\hline & \multirow{2}{*}{$\begin{array}{l}\text { Defensive } \\
(2.429)\end{array}$} & $\begin{array}{c}\text { Accommodative } \\
(4.329)\end{array}$ & -1.900 & -8.902 & $0.000^{* * * *}$ \\
\hline & & $\begin{array}{c}\text { No action } \\
(2.652)\end{array}$ & -0.224 & -1.041 & 0.585 \\
\hline & \multirow{2}{*}{$\begin{array}{l}\text { No action } \\
(2.652)\end{array}$} & $\begin{array}{c}\text { Accommodative } \\
(4.329)\end{array}$ & -1.676 & -7.641 & $0.000^{* * * *}$ \\
\hline & & $\begin{array}{c}\text { Defensive } \\
(2.429)\end{array}$ & 0.224 & 1.041 & 0.585 \\
\hline
\end{tabular}

Note: $* \mathrm{p}<0.05, * * \mathrm{p}<0.01, * * * \mathrm{p}<0.001$

In order to verify $\mathrm{H} 3$, the following interaction analysis was conducted. Table 2 shows that the interaction between response strategy and argument strength has no significant impact on corporate image $\left(\mathrm{F}_{(2,174)}=1.279 ; \mathrm{p}\right.$ $>0.05$ ), which indicates that the impact of response strategy on corporate image is not affected by argument strength. Therefore, H3a is has not been verified. 
Table 4 and Figure 1 show that the interaction between response strategy and argument strength does have a significant impact on purchase intention $\left(\mathrm{F}_{(2,174)}=3.119^{*} ; \mathrm{p}<0.05\right)$, indicating that the influence of response strategy on purchase intention will vary depending on argument strength. Therefore, H3b is supported. The changes in the scenario are clarified by the interaction between variables in the following figures and tables. First, as seen from Figure 1, no matter what the argument strength, the accommodative strategy is significantly better than the other two strategies for the promotion of purchase intention. This result is consistent with the previous two hypothesis verifications. In addition, from the pairwise average test values in Table 6, we can see the interaction that will occur when the company adopts an accommodative strategy. When the company adopts a accommodative strategy to deal with the complaints of the weak argument, the purchase intention promotion effect will be significantly greater than that in a strong argument situation $\left(\mathrm{Mean}_{\text {accommodative, strong }}=3.962<\right.$ Mean $\left._{\text {accommodative, weak }}=4.965 ; \mathrm{t}=-2.481^{*}, \mathrm{p}<0.05\right)$. This indicates that when a consumer's complaint shows a weak tone and the company adopts an accommodative strategy, there will be greater benefits to the improvement of purchase intention.

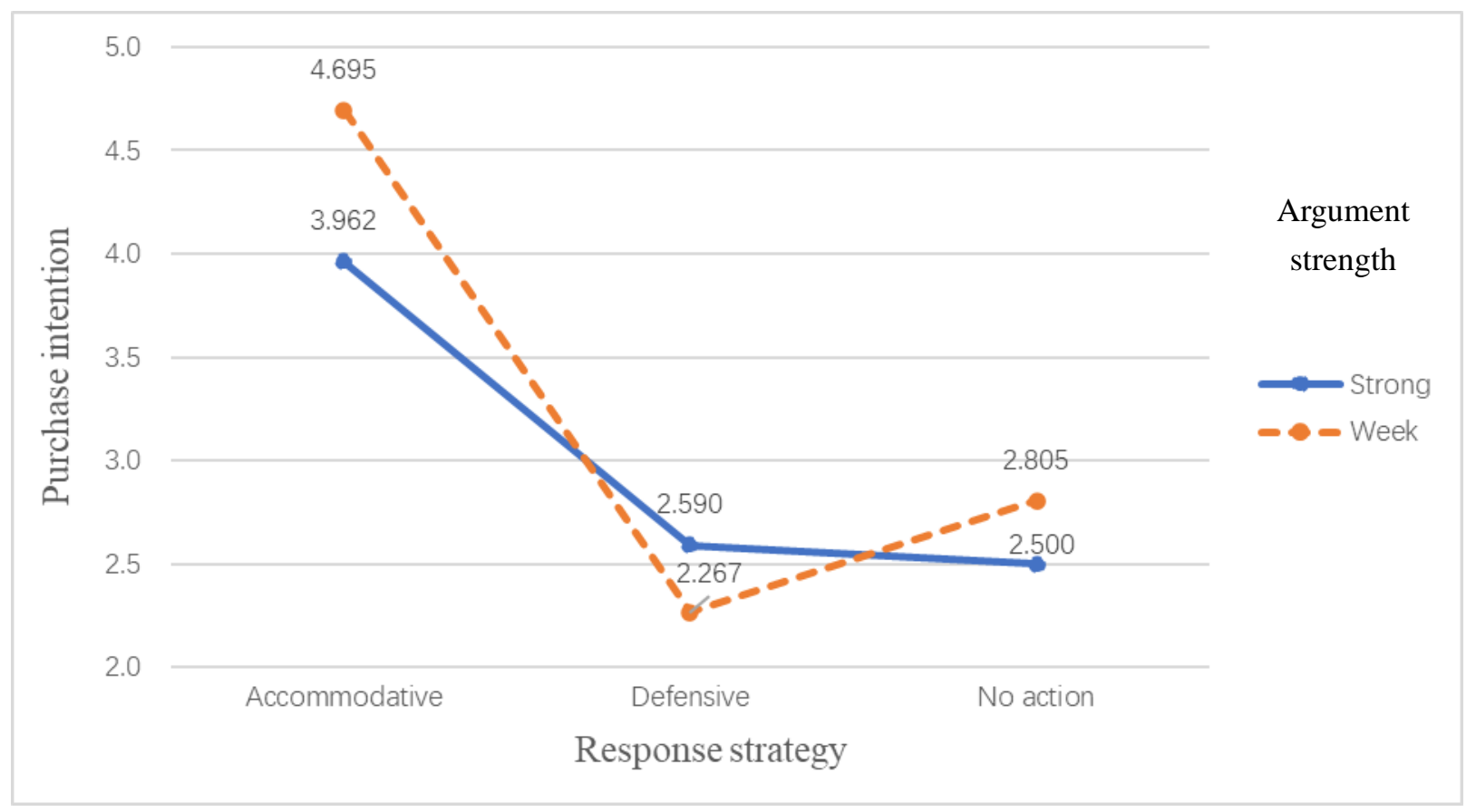

Figure 1. Interaction effect between response strategy and argument strength on purchase intention

Table 6. The analysis of the moderating effect

\begin{tabular}{|c|c|c|c|c|c|c|}
\hline Dependent variable & $\begin{array}{c}\text { Response } \\
\text { strategy }\end{array}$ & $\begin{array}{l}\text { Argument } \\
\text { strength }\end{array}$ & Mean & $\begin{array}{c}\text { Mean } \\
\text { difference }\end{array}$ & t-value & p-value \\
\hline \multirow{3}{*}{ Purchase intention } & Accommodative & $\begin{array}{l}\text { Strong } \\
\text { Weak }\end{array}$ & $\begin{array}{l}3.962 \\
4.695\end{array}$ & -0.733 & -2.481 & $0.016^{*}$ \\
\hline & Defensive & $\begin{array}{l}\text { Strong } \\
\text { Weak }\end{array}$ & $\begin{array}{l}2.590 \\
2.267\end{array}$ & 0.324 & 1.908 & 0.277 \\
\hline & No action & $\begin{array}{l}\text { Strong } \\
\text { Weak }\end{array}$ & $\begin{array}{l}2.500 \\
2.805\end{array}$ & \multirow[t]{2}{*}{-0.305} & \multirow[t]{2}{*}{-0.976} & \multirow[t]{2}{*}{0.333} \\
\hline Note: ${ }^{*} \mathrm{p}<0.05,{ }^{* *} \mathrm{p}<0$ & ${ }^{* * * *} \mathrm{p}<0.001$ & & & & & \\
\hline
\end{tabular}

In order to verify the correlation between corporate image and purchase intention, this study used regression analysis. From Table 7, we can see that the regression model explains $76.28 \%$ of the variation of $\mathrm{R}^{2}$, which exceeds the threshold of 0.5 for $\mathrm{R}^{2}$ proposed by scholars (Shin, et al., 2010). This indicates good fit for this regression model. Table 7 also shows that the regression coefficient of corporate image is 0.873 , and the p-value 
is less than 0.05 , indicating that the variables of corporate image and purchase intention are significantly positively correlated. This means that when consumers perceive a better corporate image, they have greater purchase intentions. Therefore, $\mathrm{H} 4$ is supported.

Table 7. The result of regression analysis

\begin{tabular}{|c|c|c|c|c|}
\hline \multicolumn{5}{|c|}{ Dependent variable: Purchase intention } \\
\hline Independent variable & Coefficient & t-value & p-value & Result \\
\hline Corporate image & 0.873 & 23.848 & $0.000^{* * *}$ & Accept H4 \\
\hline
\end{tabular}

$\mathrm{R}^{2}=0.762, \mathrm{R}^{2} \alpha=0.760, \mathrm{~F}=568.748, \mathrm{df}=1$

Note: $* \mathrm{p}<0.05, * * \mathrm{p}<0.01, * * * \mathrm{p}<0.001$

\section{Discussion and Conclusions}

\subsection{Conclusions}

First, this study analyzed the impact of three different company response strategies on corporate image and purchase intention. As the test results indicated, different response strategies have varying influences on corporate image and purchase intention. Among them, the accommodative strategy is significantly better than the defensive strategy and no action strategy. To maintain corporate image and strengthen purchase intention, companies should properly respond to and deal with consumer complaints. They must apologize first and then understand and deal with the problem further; to shirk responsibility or fail to respond is an unwise reaction to negative word of mouth.

Another highlight of this study is the use of argument strength as a moderator of the effects of negative WOM response strategies and the attempt to further explore whether the impact of response methods on corporate image and purchase intention will change based on the argument strength of consumers' complaints. Results indicated that argument strength only moderated the correlation between response strategy and purchase intention; it did not meet the expectation to also moderate the correlation between response strategy and corporate image.

As shown in Figure 1, regardless of argument strength, the accommodative strategy was significantly better than the other two strategies. This result is consistent with H1 and H2. Furthermore, Table 6 shows that the moderating effect of argument strength only occurred when the company adopted an accommodative strategy. When a company faces a complaint with a weak argument, the best benefits for the promotion of consumer purchase intention will be produced if an accommodative strategy is adopted. Finally, this study also validated the positive correlation between corporate image and purchase intention, highlighting the importance of the enhancement of corporate image in enhancing purchase intention. This finding is consistent with research by Bataineh (2015).

\subsection{Marketing Implications and Contributions}

This study learned from the practical observation of online customer opinions and complaints regarding financial units that the response of most of today's bankers when facing negative eWOM is no action. This study shows that actually, companies adopting an accommodative strategy in response to negative eWOM have the best results in recovering corporate image and purchase intention. Bankers and other service providers are advised not to turn a blind eye to online customer complaints, or to refute, push, or blame; instead, they should adopt an accommodative strategy and immediately apologize to the customer, explain the follow-up process, and provide the contact information of the subsequent processing personnel. In addition to alleviating customer dissatisfaction in the first instance, this gives customers reasonable expectations for the company's service failure understanding and processing time and wins even more buffer time for the company.

Moreover, if the company wants to either implement an accommodative strategy or take no action, argument strength is particularly important, especially for accommodative strategies. The above findings suggest that the company immediately make substantial remedies when the service failure occurs: provide financial value-added methods for atonement such as coupons, discounts, refunds, product replacement or re-service, etc. (Tsao \& Jhang, 2019). Moreover, managers with higher ranks can be invited to come forward to understand and remedy related incidents. They should strive to reduce consumer dissatisfaction in the moment when errors occur so as to reduce the argument strength on the Internet afterwards and enhance the effectiveness of accommodative strategies. Furthermore, from a positive point of view, good remedies can also increase customer post-recovery satisfaction, increase consumer loyalty, or slow down customer defection (Tsao, 2018). 
This study took the banking industry as its subject of research. From the perspective of argument strength, it discussed the effect of company response strategies on corporate image and purchase intention. This was done to supplement research gaps that have been generated in the past by focusing on the personal views of consumers to study negative eWOM. This study provides strategies for bankers to effectively respond to negative eWOM from consumers. Related practical applications are also applicable to service industries with high personnel involvement, such as restaurants or hotels.

\subsection{Limitations and Directions for Future Research}

Because this study was limited by manpower and funding, the effective number of samples was only 180 . Judging from its characteristics, the sample was too concentrated on students, and it is subject to certain restrictions in projecting its results onto the population as a whole. Although the questionnaire contained initial instructions to watch the content of the situation design to the end, due to the layout of the online form the subject could skip the situation design content, resulting in too many invalid questionnaires. However, strict evaluation criteria were still adopted by this study to check the validity of the questionnaires. Participant suggestions from an open question implied that there were too many questions to fill in, so participants' willingness to cooperate may have been reduced, resulting in more difficulties for controlling the quality of the answers.

Finally, relevant suggestions for future researchers are as follows: (1) This study was set up for the banking industry, so follow-up studies can be conducted for different types of industries. Analysis and comparison of differences between industries can then be carried out; (2) The only moderator in this research model was argument strength. The status of online complaint writers seems to be worth investigating in the model. With this, a clearer understanding of the effect of a company's response strategy for complaint handling could be reached.

\section{References}

Alpert, F. H., \& Kamins, M. A. (1995). An empirical investigation of consumer memory, attitude, and perceptions toward pioneer and follower brands. Journal of Marketing, 59(4), 34-45. https://doi.org/10.1177/002224299505900403

Banking Bureau, Financial Supervisory Commission of Taiwan (2019). Statistics Table of Contents of Public Appeal Cases. Retrieved from https://www.banking.gov.tw/ch/home.jsp?id=331\&parentpath=0,6

Barnett, M. L., Jermier, J. M., \& Lafferty, B. A. (2006). Corporate reputation: The definitional landscape. Corporate Reputation Review, 9(1), 26-38. https://doi.org/10.1057/palgrave.crr.1550012

Bataineh, A. Q. (2015). The Impact of Perceived e-WOM on purchase intention: The mediating role of corporate image. International Journal of Marketing Studies, 7(1), 126. https://doi.org/10.5539/ijms.v7n1p126

Beneke, J., de Sousa, S., Mbuyu, M., \& Wickham, B. (2015). The effect of negative online customer reviews on brand equity and purchase intention of consumer electronics in South Africa. The International Review of Retail, Distribution and Consumer Research, 26(2), 171-201. https://doi.org/10.1080/09593969.2015.1068828

Bradford, J. L., \& Garrett, D. E. (1995). The effectiveness of corporate communicative responses to accusations of unethical behavior. Journal of Business Ethics, 14(11), 875-892. https://doi.org/10.1007/ BF00882067

Briggs, R., \& Nigel, H. (1997). Advertising on the web: Is there response before click-through, Journal of Advertising Research, 37(2), 33-45.

Casalo, L. V., Flavián, C., \& Guinalíu, M. (2007). The influence of satisfaction, perceived reputation and trust on a consumer's commitment to a website. Journal of Marketing Communications, 13(1), 1-17. https://doi.org/10.1080/13527260600951633

Chang, H. H., Tsai, Y. C., Wong, K. H., Wang, J. W., \& Cho, F. J. (2015). The effects of response strategies and severity of failure on consumer attribution with regard to negative word-of-mouth. Decision Support Systems, 71, 48-61. https://doi.org/10.1016/j.dss.2015.01.007

Cheung, C. M. Y., Sia, C. L., \& Kuan, K. K. (2012). Is this review believable? A study of factors affecting the credibility of online consumer reviews from an ELM perspective. Journal of the Association for Information Systems, 13(8), 618. https://doi.org/10.17705/1jais.00305

Chu, S. C., Lien, C. H., \& Cao, Y. (2019). Electronic word-of-mouth (eWOM) on WeChat: Examining the influence of sense of belonging, need for self-enhancement, and consumer engagement on Chinese travelers eWOM. International Journal of Advertising, 38(1), 26-49. 
https://doi.org/10.1080/02650487.2018.1470917

Coombs, W. T., \& Holladay, S. J. (2008). Comparing apology to equivalent crisis response strategies: Clarifying apology's role and value in crisis communication. Public Relations Review, 34(3), 252-257. https://doi.org/10.1016/j.pubrev.2008.04.001

Dean, D. H. (2004). Consumer reaction to negative publicity: Effects of corporate reputation, response, and responsibility for a crisis event. The Journal of Business Communication (1973), 41(2), 192-211. https://doi.org/10.1177/0021943603261748

Dimmock, J. A., Jackson, B., Clear, S. E., \& Law, K. H. (2013). Matching temporal frame to recipients' time orientation in exercise messaging: Does argument quality matter? Psychology of Sport and Exercise, 14(6), 804-812. https://doi.org/10.1016/j.psychsport.2013.06.002

East, R., Hammond, K., \& Lomax, W. (2008). Measuring the impact of positive and negative word of mouth on brand purchase probability. International journal of research in marketing, 25(3), 215-224. https://doi.org/10.1016/j.jiresmar.2008.04.001

Fornell, C., \& Larcker, D. F. (1981). Evaluating structural equation models with unobservable variables and measurement error. Journal of marketing research, 18(1), 39-50. https://doi.org/10.1177/002224378101800104

Graham, M. E., \& Bansal, P. (2007). Consumers' willingness to pay for corporate reputation: the context of airline companies. Corporate reputation review, 10(3), 189-200. https://doi.org/10.1057/palgrave.crr.1550052

Hawkins, H. C., Best, A., \& Coney, K. (2001). Consumer Behaviour: Segmentation customers by demographic profile.

Hayes, J. L., Shan, Y., \& King, K. W. (2018). The interconnected role of strength of brand and interpersonal relationships and user comment valence on brand video sharing behaviour. International Journal of Advertising 37(1), 142-64. https://doi.org/10.1080/02650487.2017.1360576

Herbig, P., \& Milewicz, J. (1995). The relationship of reputation and credibility to brand success. Journal of consumer marketing, 12(4), 5-11.

Jan, M. T., Anuar, N. S. M., \& Sultan, N. (2018). factors influencing satisfaction with service recovery and word-of-mouth: an empirical study of banking industry in Malaysia. International Journal of Accounting, 3(16), 48-57.

Khan, A., \& Azam, M. K. (2016). Factors influencing halal products purchase intention in India: preliminary investigation. IUP Journal of Marketing Management, 15(1), 20.

Kim, S. J., Maslowska, E., \& Malthouse, E. C. (2018). Understanding the effects of different review features on purchase probability. International Journal of Advertising 37(1), 29-53. https://doi.org/10.1080/02650487.2017.1340928

Lee, C. H., \& Cranage, D. A. (2014). Toward understanding consumer processing of negative online word-of-mouth communication: the roles of opinion consensus and organizational response strategies. Journal of Hospitality \& Tourism Research, 38(3), 330-360. https://doi.org/10.1177/1096348012451455

Lee, W. J. (2012). The research of the electronic word of mouth on purchase intention. Degree Thesis of Institute of Information Management, Taipei University of Science and Technology, 1-69.

Lee, Y. L., \& Song, S. (2010). An empirical investigation of electronic word-of-mouth: Informational motive and corporate response strategy. Computers in Human Behavior, 26(5), 1073-1080. https://doi.org/10.1016/j.chb.2010.03.009

Lyu, J. C. (2012). A comparative study of crisis communication strategies between Mainland China and Taiwan: The melamine-tainted milk powder crisis in the Chinese context. Public Relations Review, 38(5), 779-791. https://doi.org/10.1016/j.pubrev.2012.07.003

Matute, J., Polo-Redondo, Y., \& Utrillas, A. (2016). The influence of EWOM characteristics on online repurchase intention: Mediating roles of trust and perceived usefulness. Online Information Review, 40(7), 1090-1110. https://doi.org/10.1108/OIR-11-2015-0373

McCollough, M. A. (2000). The effect of perceived justice and attributions regarding service failure and recovery on post-recovery customer satisfaction and service quality attitudes. Journal of Hospitality \& 
Tourism Research, 24(4), 423-447. https://doi.org/10.1177/109634800002400402

Miller, R., \& Lessard, D. (2001). Understanding and managing risks in large engineering projects. International Journal of Project Management, 19(8), 437-443. https://doi.org/10.1016/S0263-7863(01)00045-X

Nguyen, N., \& Leblanc, G. (2001). Corporate image and corporate reputation in customers' retention decisions in services. Journal of retailing and Consumer Services, 8(4), 227-236. https://doi.org/10.1016/S0969-6989(00)00029-1

Petty, R. E., \& Cacioppo, J. T. (1986). The elaboration likelihood model of persuasion. In Communication and persuasion. Springer, New York, NY, 1-24. https://doi.org/10.1007/978-1-4612-4964-1_1

Robertson, T. S., \& Gatignon, H. (1986). Competitive effects on technology diffusion. Journal of Marketing, 50(3), 1-12. https://doi.org/10.1177/002224298605000301

Schreiner, C., Appel, M., Isberner, M. B., \& Richter, T. (2018). Argument strength and the persuasiveness of stories. Discourse processes, 55(4), 371-386. https://doi.org/10.1080/0163853X.2016.1257406

Sherell, D. L., \& Reidenbach, E. R. (1986). A Consumer Response Framework for Negative Publicity: Suggestions for Response Strategies. Akron Business and Economic Review, 17(2), Summer, 37-44.

Spears, N., \& Singh, S. N. (2004). Measuring Attitude Toward the Brand and Purchase Intentions. Journal of Current Issues \& Research In Advertising (CTC Press), 26(2), 53-66. https://doi.org/10.1080/10641734.2004.10505164

Thomas, A., Brunner, M., \& Opwis, K. (2006). Satisfaction, image and loyalty: new versus experienced customers. European Journal of Marketing, 42, 9-10. https://doi.org/10.1108/03090560810891163

Tkalac Verčič, A., Verčič, D., \& Coombs, W. T. (2019). Convergence of crisis response strategy and source credibility: Who can you trust? Journal of Contingencies and Crisis Management, 27(1), 28-37. https://doi.org/10.1111/1468-5973.12229

Tsao, W. C. (2018). Star power: the effect of star rating on service recovery in the hotel industry. International Journal of Contemporary Hospitality Management, 30(2), 1092-1111. https://doi.org/10.1108/IJCHM-05-2016-0247

Tsao, W. C., \& Jhang, J. Y. (2019). Are Gender and Appearance Important? Exploring the Relationship between Recovery Type and Post-recovery Satisfaction. International Business Research, 12(5), 1-13. https://doi.org/10.5539/ibr.v12n5p1

Tsao, W. C., Hsieh, M. T., Shih, L. W., \& Lin, T. M. (2015). Compliance with eWOM: The influence of hotel reviews on booking intention from the perspective of consumer conformity. International Journal of Hospitality Management, 46, 99-111. https://doi.org/10.1016/j.ijhm.2015.01.008

Tucker, L., \& Melewar, T. C. (2005). Corporate reputation and crisis management: The threat and manageability of anti-corporatism. Corporate reputation review, 7(4), 377-387. https://doi.org/10.1057/palgrave.crr.1540233

Zhang, C. Y. (2013). The Impact Corporate Response Strategies of Online Negative Word of Mouth on Consumers: The Product Category as Moderator. Taipei University of Science and Technology Master Degree Thesis, 1-56.

Zhang, Y. (2016). Selecting risk response strategies considering project risk interdependence. International Journal of Project Management, 34(5), 819-830. https://doi.org/10.1016/j.ijproman.2016.03.001 


\section{Appendix A. Measurement Instruments}

This appendix contains the statements used in the survey. Respondents were asked to what degree they agree or disagree with these statements on a seven-point Likert scale.

Corporate image 【adapted from Stipp \& Schiavone (1996); Nguyen \& LeBlanc (2001); Ouyang \& Chen (2003);

Foroudi et al. (2014), $\alpha=.960$ 】

C1 I have a good impression of this bank.

C2 I think this bank has a good image in the minds of customers.

C3 I believe this bank's image is better than other banks.

C4 This bank's response to customer complaints has enhanced its corporate image.

C5 I have a positive comment regarding the bank's customer complaint response.

C6 I will prefer do business with this bank because of its response to customer complaints.

C7 Overall, I respect the corporate image of this company.

\begin{tabular}{l} 
Purchase intention 【adapted from Dodson et al. (1978); Stipp \& Schiavone (1996); Sheng et al. (2007); Lu et al. \\
(2016), $\alpha=.966 】$ \\
\hline P1 I will go to this bank to conduct business. \\
P2 Among the banks I know, I will choose this bank to conduct business. \\
P3 I have a high chance of going to this bank to conduct business. \\
P4 I will recommend friends and family to go to this bank to conduct business. \\
P5 This bank is my first choice to conduct business. \\
P6 I will change from another bank to this bank because of the way it responds to customers. \\
P7 Overall, I am willing to go to this bank to conduct business. \\
\hline Argument strength 【adapted from Dimmock et al. 2013); Schreiner et al. (2018), $\alpha=.793$ 】 \\
\hline A1 I think that the consumer's message is strong in words. \\
A2 I think the description in the consumer's message is realistic. \\
A3 I think the description of the consumer's message is clear.
\end{tabular}

\section{Copyrights}

Copyright for this article is retained by the author(s), with first publication rights granted to the journal.

This is an open-access article distributed under the terms and conditions of the Creative Commons Attribution license (http://creativecommons.org/licenses/by/4.0/). 